\title{
The EB virus in relation to infectious mononucleosis
}

\author{
R. N. P. SUTTON \\ From the Department of Microbiology, King's College Hospital Medical School, London
}

Chance favours the prepared mind and it was a fortunate circumstance that the Henles were studying the Epstein-Barr (EB) virus (Epstein, 1970) when one of their technicians, whose serum was being used as a negative control, fell ill with typical infectious mononucleosis. During this illness, she developed not only heterophile antibodies but also fluorescent antibodies to the EB virus (Henle, Henle, and Diehl, 1968). In another example of forethought, sera had been taken at intervals over the years from university students. Examination of these confirmed the association between the development of infectious mononucleosis and the acquisition of antibodies to the EB virus (Evans, Niederman, and McCollum, 1968). Subsequent studies (Niederman, Evans, Subrahmanyan, and McCollum, 1970; Sawyer, Evans, Niederman, and McCollum, 1971, Joint Investigation by University Health Physicians and Public Health Laboratory Service Laboratories, 1971) have shown convincingly that fluorescent antibodies to the EB virus develop during illnesses which are clinically recognizable as infectious mononucleosis and which are associated with the development of a positive Paul-Bunnell test and the appearance of typical abnormal lymphocytes in the peripheral blood. Infectious mononucleosis which is unassociated with the development of a positive Paul-Bunnell test may be associated with cytomegalovirus infection (Klemola and Kääriäinen, 1965; Lamb and Stern, 1966) but is uncommonly associated with EB virus infection (Klemola, von Essen, Henle, and Henle, 1970).

The transmission of EB virus in man has been observed on several occasions. Grace, Blakeslee, and Jones (1969) inoculated serologically negative volunteers with cell extracts which contained EB virus: infectious mononucleosis developed in these individuals and they acquired EB virus antibodies. Accidental infection following perfusion with presumably infected blood has been described (Gerber, Walsh, Rosenblum, and Purcell, 1969) but Stevens and Pry (1971) considered this to be a rare event. Kapsenberg, Langenhuysen, Nieweg, and Deiss (1970) observed clinical infectious mononucleosis in a girl of 17 which followed a blood trans- fusion; she developed high levels of antibody to cytomegalovirus and also to EB virus. Spread of EB virus infection, with or without overt illness, has been detected in family and social contacts of children and young adults with infectious mononucleosis (Wahren, Lantorp, Sterner, and Espmark, 1970; Joncas and Mitnyan, 1970); the latter authors remarked upon the apparent low infectivity of this virus. To date, there have been no reports of the production of infectious mononucleosis in animals following the administration of EB virus, although Landon and Malan (1971) observed the decline of (probably) maternal antibodies in three species of macaque monkeys kept in captivity and tested over a period of months. Similarly, Gerber and Rosenblum (1968) have found EB virus antibodies in rhesus monkeys.

Although infectious mononucleosis is commonly associated with EB virus infection, there is much evidence that many infections must be asymptomatic or nearly so. Thus, Lehane (1970) in a prospective study of a military population, demonstrated a ratio of 1:10 in apparent to inapparent cases of infectious mononucleosis associated with EB virus serological conversion. In our own medical students and nurses, tested on entry for antibodies to rubella and to EB viruses, we found a close relationship between a history of past illness and the presence of antibodies to these viruses (Table I). More had rubella antibodies $(80 \%)$ than EB virus antibodies

\begin{tabular}{llll}
\hline & $\begin{array}{l}\text { Rubella } \\
\text { (Rubella virus) })\end{array}$ & $\begin{array}{l}\text { Infectious } \\
\text { Mononucleosis } \\
(E B \text { virus })\end{array}$ & $\begin{array}{l}\text { Significance of } \\
\text { Differences } \\
\left(x^{2} \text { test }\right)\end{array}$ \\
\hline $\begin{array}{l}\text { No. tested } \\
\begin{array}{l}\text { No. with past } \\
\text { history of illness }\end{array}\end{array}$ & 273 & 224 & \\
$\begin{array}{l}\text { No. with anti- } \\
\text { bodies to } \\
\text { relevant virus }\end{array}$ & $219 / 273(80 \%)$ & $144 / 224(64 \%)$ & $\mathrm{P}<0.001$ \\
$\begin{array}{l}\text { No with past } \\
\text { history of } \\
\text { illness + anti- } \\
\text { bodies to } \\
\text { relevant virus }\end{array}$ & $147 / 163(90 \%)$ & $20 / 24(83 \%)$ & Not significant \\
\hline
\end{tabular}

Table I Rubella and infectious mononucleosis in medical students and nurses 
$(64 \%)$ but, whereas $67 \%$ gave a history of rubella, only $11 \%$ gave a history of infectious mononucleosis or glandular fever. Antibody studies in groups of varying ages agree with this (Henle, Henle, and Diehl, 1968; Pereira, Blake, and Macrae, 1969; University Health Physicians and P.H.L.S. Laboratories Joint Investigation, 1971) for whilst antibodies appear to be acquired throughout childhood, the peak incidence of clinical infectious mononucleosis is not found until early adult life (Newell, 1957).

The evidence thus indicates that infectious mononucleosis with a positive Paul-Bunnell test is often associated with $E B$ virus infection but most infections with this virus are asymptomatic. Although generally accepted that the relationship is a fairly straightforward one, sceptics such as Glade, Hirschhorn, and Douglas (1969) consider that the antibody responses represent non-specific reactions to a variety of stimuli by a virus which is a harmless symbiont. Stevens, Pry, and Manaker (1970) have questioned whether infectious mononucleosis is always a primary infection with EB virus and have demonstrated instances where sera taken long before the onset of illness showed moderate levels of fluorescent antibody. In this context, Grace et al (1969) showed anamnestic serological responses but no illness in individuals who were re-inoculated with EB virus following recovery from experimental infection.

Most of the above epidemiological studies on the relationship between infectious mononucleosis and EB virus infection have depended upon the demonstration of antibodies by indirect fluorescence (Henle and Henle, 1966). Knowledge of EB virus replication is now rather fuller and has disclosed a range of antigens which arise during this process. These antigens and the antibodies which may be produced against them may be detected in a variety of ways.

\section{Antibodies to the EB Virus}

FLUORESCENT ANTIBODIES (VIRAL CAPSID ANTIGEN ANTIBODIES)

The indirect fluorescent antibody test, using cells fixed in acetone (Henle and Henle, 1966), was the first method for detecting EB virus antibodies to be described and is usually the one which is implied when no other indication is given. These antibodies are directed towards the virus capsid (Zur Hausen, Henle, Hummeler, Diehl, and Henle, 1967; Epstein and Achong, 1968; Henle, Henle, Zajac, Pearson, Waubke, and Scriba, 1970) and are now termed viral capsid antigen (VCA) antibodies. This antigen develops late during virus replication and, as it is associated with the virus particle, is not detectable in cell lines which are substantially 'virus-free' (as determined by electron microscopy), such as the Raji cell line or probably the RM cell line which we derived from a patient with infectious mononucleosis. During infectious mononucleosis, VCA antibodies develop rapidly and may be present shortly before the onset of frank illness. As they are present in over half of the age group in which infectious mononucleosis is commonly observed, their presence or absence is of little use in the diagnosis of this disease unless, of course, sera taken before the onset of illness are available. Viral capsid antigen antibodies decline gradually (Niederman et al, 1970) but may show considerable fluctuations (Sohier, 1970).

ANTIBODIES TO CELL MEMBRANE ANTIGENS Cell membrane antigens were initially detected by indirect immunofluorescence in living Burkitt tumour cells (Klein, Clifford, Klein, and Stjernsward, 1966) but difficulties in standardization led to the use of established cell culture lines and a blocking technique with a standard serum that was shown to be free from iso-antibodies (Klein, Clifford, Klein, Smith, Minowada, Kourilsky, and Burchenal, 1967). The membrane antigen is associated with the virus capsid but differs from the VCA antigen and is probably an early product of virus synthesis, as its formation is not inhibited by cytosine arabinoside or IUDR, whereas puromycin inhibits it completely (Gergely, Klein, and Ernberg, 1971). It can be detected in cultured cells derived from patients with infectious mononucleosis (Klein, Pearson, Henle, Henle, Diehl, and Niederman, 1968) and these patients develop antibodies to cell membrane antigens.

\section{ANTIBODIES TO EARLY ANTIGEN}

During the course of experimental infections of foetal lymphoblastoid cells with EB virus (Henle, Diehl, Kohn, Zur Hausen, and Henle, 1967; Pope, Horne, and Scott, 1968; Dunkel and Ziegel, 1970), a further antigen, the early antigen (EA), was detected (Henle, Henle, Ho, Burtin, Cachin, Clifford, de Schryver, de The, Diehl, and Klein, 1970; Hinuma, Sairenji, and Ohta-Hatano, 1971). This antigen is another early product of viral replication and is independent of viral DNA synthesis (Gergely et al, 1971). As in the case of the cell membrane antigens it has some resemblance to antigens observed in cell cultures of tumours induced experimentally by oncogenic DNA viruses (Rapp, Butel, Feldman, Kitahara, and Melnick, 1965; Rapp, 1968).

COMPLEMENT-FIXING ANTIBODIES

Armstrong, Henle, and Henle (1966) described 
complement-fixation tests with an antigen prepared by the disruption of cultured Burkitt tumour cells. Antibodies to this antigen were present in many individuals but they differed clearly from those directed against the VCA antigen. Gerber and Birch (1967) prepared a similar antigen and purified it by sucrose gradient centrifugation. They selected the fractions which contained a high proportion of virus, as assessed by electron microscopy, and observed in their serological tests a close concordance with VCA antibodies: an antigen prepared in the same way from the 'virus-free' RAJI cell line did not react with known positive sera. However, Pope, Horne, and Wetters (1969), using a crude antigen, observed complement-fixing activity in preparations of RAJI cells, as well as in preparations of virus-containing cells. It has now become clear that both soluble and sedimentable complement-fixing antigens are present in cultured Burkitt tumour cells and in cultured human leucocyte cultures (Gerber and Deal, 1970; Vonka, Benyesh-Melnick, Lewis, and Wimberly, 1970; Vonka, Benyesh-Melnick, and McCombs, 1970; Hollinshead, Lee, and Alford, 1971). Walters and Pope (1971) have separated three components of their complement-fixing antigen; these are a virion-associated component, and two soluble components, one heat-labile and one heat-resistant. Preparations from RAJI cells contain only the third of these antigenic components. These soluble antigens may also be analogous to the $T$ antigens induced by oncogenic DNA viruses (Shigeta, Minowada, and Moore, 1971).

We have been studying (Sutton, Marston, and Emond, 1971) antibodies to a soluble complementfixing antigen prepared from virus-containing EB3 cells by the method of Armstrong, Henle, and Henle (1966). A similar antigen prepared from the apparently 'virus-free' RM cell line reacted in the same way with test sera and it is thus possible that our antigen resembles the soluble antigen of Vonka et al (1970).

Over half $(64 \%)$ of medical students and nurses born in Europe or in North America possessed antibodies; almost all (95\%) of those born in tropical areas had similar evidence of previous infection (Table II). In 224 medical students and

\begin{tabular}{llc}
\hline Origin of Subjects & \multicolumn{2}{c}{$E B$ Virus Complement-fixing Antibody Titres } \\
\cline { 2 - 3 } & 4 or less & Greater than 4 \\
\hline Africa, West Indies, Asia & 1 & $23(95 \%)$ \\
Europe, North America & 80 & $144(64 \%)$ \\
& & $\mathrm{P}=0.0006$ (exact test) \\
\hline
\end{tabular}

Table II EB complement-fixing antibodies in nurses and medical students nurses born in Europe or North America there was a significant association between a history of infectious mononucleosis and the presence of complementfixing antibodies (Table III) and, in 73 patients

\begin{tabular}{lcc}
\hline $\begin{array}{l}\text { History of Infectious } \\
\text { Mononucleosis }\end{array}$ & \multicolumn{2}{c}{ EB Virus Complement-fixing Antibody Titres } \\
\cline { 2 - 3 } & 4 or Less & Greater than 4 \\
\hline Yes & 4 & 20 \\
No & 124 & 76 \\
& & $\mathrm{P}=0.02$ (exact test) \\
\hline
\end{tabular}

Table III Relation of EB complement-fixing antibodies to past history of infectious mononucleosis in medical students and nurses

admitted to hospital with infectious mononucleosis, compared with 88 patients admitted to the same hospital with other conditions, there was a significant association between low levels of complement-fixing antibodies and active infectious mononucleosis (Table IV). These patients slowly developed antibodies and, when tested some months later, almost all had acquired high levels (Table V).

\begin{tabular}{|c|c|c|}
\hline \multirow[t]{2}{*}{ Diagnosis on Admission } & \multicolumn{2}{|c|}{ EB Virus Complement-fixing Antibody Titres } \\
\hline & 4 or Less & Greater than 4 \\
\hline $\begin{array}{l}\text { Infectious mononucleosis } \\
\text { Other conditions }\end{array}$ & $\begin{array}{r}32 \\
14\end{array}$ & $\begin{array}{l}41 \\
74 \\
=13.9 \\
<0.001\end{array}$ \\
\hline
\end{tabular}

Table IV EB complement-fixing antibodies in patients with infectious mononucleosis and with other conditions

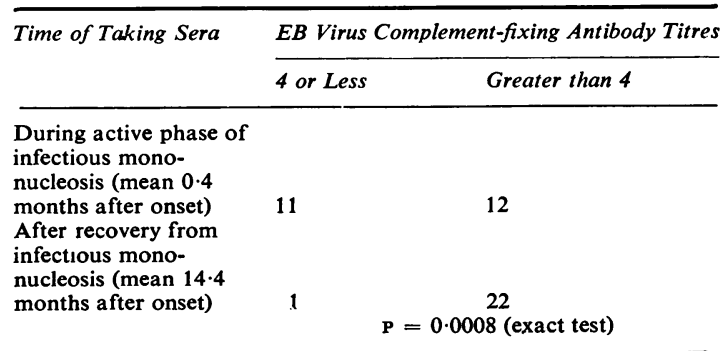

Table $\mathrm{V} \quad$ EB Complement-fixing antibodies in 23 patients with infectious mononucleosis

Unlike the VCA antibodies, soluble complementfixing antibodies to the EB virus develop slowly after the onset of illness and there is some evidence (Sutton, Almond, Marston, and Emond, 1971) that the combined use of these tests could form the basis for a differential test for recent or remote infection (Table VI). 


\begin{tabular}{|c|c|c|c|c|}
\hline & \multicolumn{4}{|c|}{ Period when Sera were Collected } \\
\hline & $\begin{array}{l}\text { Before } \\
\text { Illness }\end{array}$ & $\begin{array}{l}0-2 \text { Weeks } \\
\text { after Onset }\end{array}$ & $\begin{array}{l}2-24 \text { Weeks } \\
\text { after Onset }\end{array}$ & $\begin{array}{l}\text { Over } 25 \\
\text { Weeks after } \\
\text { Onset }\end{array}$ \\
\hline $\begin{array}{l}\text { Sera with Fluor- } \\
\text { escent Antibody } \\
\text { Titres }>8 \\
\text { Total number of } \\
\text { sera tested }\end{array}$ & $0 / 4$ & $18 / 27(67 \%)$ & $20 / 36(56 \%)$ & $23 / 28(82 \%)$ \\
\hline $\begin{array}{l}\text { Sera with Comple- } \\
\text { ment-fixing Antibody } \\
\text { Titres }>16 \\
\text { Total number of } \\
\text { sera tested }\end{array}$ & $0 / 7$ & $10 / 42(24 \%)$ & $9 / 72(12 \%)$ & $40 / 53(76 \%)$ \\
\hline $\begin{array}{l}\text { Significance of } \\
\text { differences } \\
\left(x^{2} \text { test) }\right.\end{array}$ & NS & $P<0.05$ & $P=<0.0005$ & NS \\
\hline
\end{tabular}

Table VI Development of fluorescent antibodies and complement-fixing antibodies to $E B$ virus infectious mononucleosis

\section{PRECIPITATING ANTIBODIES}

Precipitating antibodies to EB virus antigens have been described by several groups (Old, Boyse, Oettgen, De Harven, Geering, Williamson, and Clifford, 1966; Fink and Cowles, 1968; Stevens, Pry, and Blackham, 1970). Old and his colleagues, using an antigen prepared from sonicated cells and a standard Ouchterlony technique, detected such antibodies in about $50 \%$ of patients with Burkitt tumour and in a low proportion (1 of 17) of patients with infectious mononucleosis. Using this method, our results have been similar. Of 55 patients admitted to hospital with infectious mononucleosis, three developed precipitating antibodies from two to nine months after the onset of illness; these sera showed reactions of identity with each other and with a serum from a patient with a Burkitt tumour. Of 199 controls tested, one possessed precipitating antibody: this was a woman of 45 years, admitted with an unrelated complaint, who had an unusually high EB complement-fixing antibody level and who had a considerably (four-fold) raised level of gamma globulins.

Stevens et al (1970) and Fink and Cowles (1968) have used a micro-technique and claim a much greater sensitivity, the former authors finding antibodies in 121 of 261 healthy controls and in 27 of 42 patients with infectious mononucleosis. The antibodies are probably IgG (Oettgen, Aoki, Geering, Boyse, and Old, 1967) and the precipitating antigens are probably associated with EB virus particle (Stevens et al, 1970). The nature of this test lends itself to antigenic comparison, and Fink, King, and Mizell (1968) have claimed to have thus demonstrated the identity of the EB virus with the Lucke frog adenocarcinoma and Ono, Tanabe, Naito, Doi, and Kato (1970) have reported that a herpes-type virus recovered from a chicken with Marek's disease shared at least one antigen with the EB virus.

\section{The Response to Infection with EB Virus}

VIROLOGICAL

We have seen that a variety of antibodies, directed against the EB virus capsid, against the cell membrane and against several antigens which arise earlv in the replicative cycle, can be detected in patients with infectious mononucleosis, as well as in those with Burkitt's tumour or with nasopharyngeal carcinoma. These antigens appear to develop sequentially following cellular infection with the EB virus and in character they are very reminiscent of the antigens specified by some oncogenic DNA viruses, such as SV40 (Rapp, 1968). The presence of DNA virus nucleic acid homology in a virus-free line of Burkitt tumour cells (Zur Hausen and Schulte-Holthausen, 1970), and the recent demonstration by Epstein (1971) that human embryo fibroblasts can be transformed by the EB virus, are also relevant.

Some variation occurs in response to infection and deserves remark. Henle et al (1970) observed that antibodies to early antigens were rarely seen in sera other than those from patients with Burkitt's tumour, nasopharyngeal carcinoma, or infectious mononucleosis, and Pearson, Henle, and Henle (1971) noted that three lymphoblastoid cell lines responded in differing ways to experimental infection with EB virus, one line producing early antigen but not membrane or viral capsid antigens, another responding with high titres of viral capsid and membrane antigens. Such differences might well influence the expression of virus infection, acting (by analogy with herpes simplex virus) via the glycoprotein specified by the virus (Spear, Keller, and Roizman, 1970), which is detectable by an altered immunological specificity on the cell membrane (Roizman and Spring, 1967) and which is accompanied by alterations in the 'social behaviour' of the cell (Roizman, 1971). Whether these differences are due to intratypic variation in the virus or to host variation (possibly genetic in nature) is not known; in the system described by Pearson et al (1971), host variation is clearly important.

These observations chime well with our present knowledge linking the EB virus with Burkitt's lymphoma and with nasopharyngeal carcinoma, and the connexion with infectious mononucleosis is thought-provoking. Clinical infectious mononucleosis bears no patent relationship with malignant disease although, rarely, it may be followed by Burkitt's tumour (Cohen, Hirshaut, Stevens, Hull, Davis, and Carbone, 1970) or by Hodgkin's disease (English, 1970). In the later condition, elevated EB 


\begin{tabular}{|c|c|c|c|c|c|}
\hline & \multicolumn{3}{|c|}{ Immunoglobulins ( $\%$ MRC Standard Serum) } & \multirow[t]{2}{*}{ Age (years) } & \multirow[t]{2}{*}{ Number Tested } \\
\hline & $\operatorname{Ig} M$ & $\operatorname{Ig} A$ & $\operatorname{Ig} G$ & & \\
\hline $\begin{array}{l}\text { Patients with infectious mononucleosis } \\
\text { Patients with other conditions } \\
\text { t } \\
\text { P }\end{array}$ & $\begin{array}{c}269 \cdot 5^{1} \\
151 \cdot 6 \\
5.9 \\
<0.001\end{array}$ & $\begin{array}{l}197 \cdot 2^{1} \\
122 \cdot 8 \\
4 \cdot 6 \\
<0 \cdot 001\end{array}$ & $\begin{array}{l}177 \cdot 1^{1} \\
142 \cdot 6 \\
4 \cdot 5 \\
<0 \cdot 001\end{array}$ & $\begin{array}{l}19 \cdot 0^{1} \\
24 \cdot 2 \\
0 \cdot 3 \\
<0 \cdot 8 \text { (NS) }\end{array}$ & $\begin{array}{r}73 \\
82\end{array}$ \\
\hline $\begin{array}{l}\text { Medical students and nurses } \\
\text { t } \\
\text { P }\end{array}$ & $\begin{array}{l}123 \cdot 4 \\
13 \cdot 2 \\
<0 \cdot 001\end{array}$ & $\begin{array}{c}107 \cdot 6 \\
7 \cdot 3 \\
<0 \cdot 001\end{array}$ & $\begin{array}{r}123 \cdot 8 \\
5 \cdot 1 \\
<0 \cdot 001\end{array}$ & $\begin{array}{c}19.9 \\
0.18 \\
0.95(\mathrm{NS})\end{array}$ & 127 \\
\hline
\end{tabular}

Table VII Geometric mean values and Student's $t$ test analyses for age and immunoglobulins in patients with infectious mononucleosis, with other conditions, and healthy medical students and nurses

${ }^{1}$ GMTs of logarithmically transformed data.

virus antibody titres have been observed (Levine, Ablashi, Berard, Carbone, and Waggoner, 1970; Johansson, Klein, Henle, and Henle, 1970) and Reed-Sternberg-like cells have been observed in infectious mononucleosis (Lukes, Tindle, and Parker, 1969; McMahon, Gordon, and Rosen, 1970) Although there has been speculation that infectious mononucleosis is 'an atypical form of acute leukaemia with a self-limiting course' (Dameshek and Gunz, 1964), EB virus studies have not supported this and concurrent infectious mononucleosis and acute leukaemia is not uncommon (Lampkin, Canales and Mauer, 1967; Deardorff, Gerber, and Vogler, 1970; Ragab and Vietti, 1969; Stevens, Levine, Lee, Sonley, and Waggoner, 1971).

\section{IMMUNOLOGICAL}

The EB virus, by virtue of its habitat, is in a favourable position to distort humoral and cellular immune responses. Wollheim and Williams (1966) and our own group (Table VII) have observed considerable increases in immunoglobulin levels, especially in the IgM fraction, during the acute phase of infectious mononucleosis; these high levels normally decline over the ensuing weeks or months. Wollheim and Williams estimated that, in the acute phase of illness, about $5 \%$ of the IgM immunoglobulin was attributable to heterophile antibody and, as this declines rapidly, in the later stages almost all remains unaccounted for. Part of this is, presumably, virus antibody, ie, EB virus antibody, but some of this IgM immunoglobulin may be 'inappropriate antibody' (Waldenström, 1968). Thus, antinuclear factor has been observed in patients with infectious mononucleosis (Wollheim and Williams, 1966, Holborow, Asherson, Johnson, Barnes, and Carmichael, 1963; Carter, 1966), as has anti 'i' (Wollheim and Williams, 1966), rheumatoid factor (Dresner and Trombly, 1959; Holborow et al, 1963), and cryoproteins (Kaplan, 1968). In general, these abnormal antibodies are seen infrequently and, in our series, we have observed a positive latex test in one of 79 patients with infectious mononucleosis, many of whom were tested at various stages during their illness.

There has been at least one report of transient depression of cell-mediated hypersensitivity, as assessed by the tuberculın reaction. Jones (1970) observed that six of 13 patients with acute infectious mononucleosis exhibited negative reactions to tuberculin (100 TU) early in their illnesses which reverted to positive in convalescence. Of our own patients, De Coutinho (personal communication) has observed two who were given BCG at unspecified times before the illness (possibly in childhood) and were tuberculin negative during the acute phase of infectious mononucleosis, reverting to a positive state during convalescence.

\section{Conclusions}

There is good evidence that much of the population is infected with the EB virus in childhood or later. Most infections are, apparently, asymptomatic but, in some, infection with the EB virus is associated with 'Paul-Bunnell positive' (but not 'Paul-Bunnell negative') infectious mononucleosis. Following EB virus infection, whether accompanied by overt illness or not, a variety of specific antibodies develop. These are directed against the EB virus particle and against antigens specified during early stages of viral synthesis; the latter resemble antigens which are formed during experimental infections with oncogenic DNA viruses.

Infectious mononucleosis, unlike the other conditions for whose aetiology the EB virus is a candidate, is not a malignant condition. Nevertheless, the suspicion of oncogenicity attached to the EB virus and its wide prevalence in the community make closer observation of its host-virus reactions an important object for further investigations. Such work as has been done suggests that the EB virus may be responsible for abnormal humoral and cellular 
responses in man and indicates that further studies in this direction would be fruitful.

I am grateful to Dr R. T. D. Emond, Dr Hillas Smith, and Dr M. de L. Coutinho, of the Royal Free Hospital Infectious Diseases Unit, Coppetts Wood Hospital, to Mrs E. J. P. Almond, Mrs S. D. Marston, Miss H. J. M. Pullen, and Mrs K. Reynolds of the Department of Medical Microbiology, King's College Hospital Medical School, for their help in many ways, to Dr W. Henle for hospitality in his laboratory, to Professor G. Klein for the opportunity to see an unpublished typescript, and to the Cancer Research Campaign, the Joint Research Committee, King's College Hospital, and the Leukaemia Research Fund, for financial support. We are also grateful to Ortho Diagnostics for the provision of some reagents.

\section{References}

Armstrong, D., Henle, G., and Henle, W. (1966). Complement fixation tests with cell lines derived from Burkitt's lymphoma and acute leukemias. J. Bact., 91, 1257-1262.

Carter, R. L. (1966). Antibody formation in infectious mononucleosis II. Other 19s antibodies and talse-positive serology. Brit. $J$ Haemat., 12, 268-275.

Cohen, M. H., Hirshaut, Y., Stevens, D., Hull, E. W., Davis, J. H., and Carbone, P. P. (1970). Infectious mononucleosis followed by Burkitt's tumour. Ann. intern. Med., 73, 591-593.

Dameshek, W., and Gunz, F. (1964). Leukemia. 2nd ed. Grune and Stratton, New York.

Deardorff, W. L., Gerber, P., and Vogler, W. R. (1970). Infectious mononucleosis in acute leukemia with rising Epstein-Bar virus antibody titers. Ann. intern. Med., 72, 235-240.

Dresner, E., and Trombly, P. (1959). The latex fixation reaction in nonrheumatic diseases. New Engl. J. Med., 261, 981-988.

Dunkel, V. C., and Zeigel, R. F. (1970). Studies on the relation of membrane immunofluorescence to Epstein-Barr virus infection. J. nat. Cancer Inst., 44, 133-144.

English, J. M. (1970). Infections mononucleosis followed by Hodgkin's disease. (Letter to the Editor). Lancet, 1, 948.

Epstein, M. A. (1970). Aspects of the EB virus. Advanc. Cancer Res. 13, 384-411.

Epstein, M. A., and Achong, B. G. (1968). Specific immunofluorescence test for the herpes-type EB virus of Burkitt lymphoblasts, authenticated by electron microscopy. J. nat. Cancer Inst., 40, 593-607.

Evans, A. S., Niederman. J. C., and McCollum, R. W. (1968). Seroepidemiologic studies of infectious mononucleosis with EB virus. New Engl. J. Med., 279, 1121-1127.

Fink, M. A., and Cowles, C. A. (1968). Use of immunological techniques in the study of human leukemia. In Proceedings of the International Conference on Leukemia-Lymphoma, edited by C. J. D Za rafonetis, pp. 155-162. Lea and Febiger, Philadelphia.

Fink, M. A., King, G. S., and Mizell, M. (1968). Prelimina ry note: identity of a herpesvirus antigen from Burkitt lymphoma of man and Luckć adenocarcinoma of frog. J. nat. Cancer Inst., 41, 1477-1478.

Gerter, P., and Birch, S. M. (1967). Complement fixing antibodies in sera of human and non-human primates to viral antigens derived from Burkitt's lymphoma cells. Proc. nat. Acad. Sci. (Wash.), 58, 478-484.

Gerber, P., and Deal, D. R. (1970). Epstein-Barr virus induced viral and soluble complement-fixing antigens in Burkitt lymphoma cell cultures, Proc. Soc, esp. Biol. (N.Y.), 134, 748-751.

Gerber, P., and Rosenblum, E. N. (1968). The incidence of complement fixing antibodies to herpes simplex and herpes-like viruses in man and rhesus monkeys. Proc. Soc. exp. Biol. (N.Y.), 128, 541-546.
Gerber, P. Walsh, J. H., Rosenblum, E. N., and Purcell, R. H. (1969). Association of EB virus infection with the post-perfusion syndrome. Lancet, 1, 593-596.

Gergely, L., Klein, G., and Ernberg, I. (1971). The action of DNA antagonists on Epstein-Barr virus (EBV)-associated early antigen (EA) in Burkitt lymphoma cell lines. Int. J. Cancer, 7 , 293-302.

Glade, P. R., Hirschhorn, K., and Douglas, S. D. (1969). Herpes-like virus. (Letter to the Editor). Lancet, 1, 1049-1050.

Grace, J. T., Jr., Blakeslee, J., Jr., and Jones, R., Jr. (1969). Induction of infectious mononucleosis in man by the herpes-like virus (HTV) in Burkitt lymphoma cells in tissue culture. (Abstr.) Proc. Amer. Ass. Cancer Res., 10, 31

Henle, W., Diehl, V., Kohn, G., zur Hausen, H., and Henle, G. (1967). Herpes-type virus and chromosome marker in normal leukocytes after growth with irradiated Burkitt cells. Science, 157 1064-1065.

Henle, G., and Henle, W. (1966). Immunofiuorescence in cells derived from Burkitt's lymphoma. J. Bact., 91, 1248-1256.

Henle, W., Henle, G., Ho, H. C., Burtin, P., Cachin, Y., Clifford, P., de Schryver, A., de The, G., Diehl, V., and Klein, G. (1970). Antibodies to the Epstein-Barr virus in nasopharyngea carcinoma, other head and neck neoplasms and control groups. $J$. nat. Cancer Inst., 44, 225-231.

Henle, G., Henle, W., and Diehl, V. (1968). Relation of Burkitt's tumor-associated herpes-type virus to infectious mononucleosis. Proc. nat. Acad. Sci. (Wash.), 59, 94-101.

Henle, W., Henle, G., Zajac, B. A., Pearson, G., Waubke, R., and Scriba, M. (1970). Differential reactivity of human serums with early antigens induced by the Epstein-Barr virus. Science, 169 188-190.

Hinuma, Y., Sairenji, T., and Ohta-Hatano, R. (1971). Detection of antibody to a new antigen induced by Epstein-Barr virus in serums from patients with malignant lymphoid diseases. Proc. Jap. Acad., 46, 989-992.

Holborow, E. J., Asherson, G. L., Johnson, G. D., Barnes, R. D. S. and Carmichael, D. S. (1963). Antinuclear factor and other antibodies in blood and liver diseases. Brit. med. $J, 1,656-658$.

Hollinshead, A., Lee, O'B., and Alford, T. C. (1971). Localization of complement-fixing antigens in cells: Epstein-Barr virus induced membrane and interior antigens. J. gen. Virol., 13 , 441-447.

Johansson, B., Klein, G., Henle, W., and Henle, G. (1970). EpsteinBarr virus (EBV) associated antibody patterns in malignan lymphoma and leukaemias; I. Hodgkin's disease. Int.J. Cancer, $6,450-462$.

Joncas, J., and Mitnyan, C. (1970). Serological response of EBV antibodies in pediatric cases of infectious mononucleosis and in their contacts. Canad. med. Ass. J., 102, 1260-1263.

Jones, J. V. (1970). Depression of delayed hypersensitivity in chronic granulomatous conditions In Proceedings of the Third Symposium on Impaired Cell-Mediated Hypersensitivity in Man, edited by J. F. Jennings and D. J. Ward, pp. 81-88. Robert Jones and Agnes Hunt Orthopaedic Hospital Management Committee Oswestry.

Kaplan, M. E.(1968). Cryoglobulinemia in infectious mononucleosis quantitation and characterization of the cryoproteins. J. Lab clin. Med., 71, 754-765.

Kapsenberg, J. G., Langenhuysen, M. M. A. C., Nieweg, H. O., and Deiss, H. (1970). Posttransfusion mononucleosis with heterophil antibodies; simultaneous infection with CMV and EB virus. Acta med. scand., 187, 79-82.

Klein, G. Clifford, P. Klein, E., and Stjernsward, J. (1966). Search for tumor specific immune reactions in Burkitt lymphoma patients by the membrane immunofluorescence reaction. Proc. nat. Acad. Sci. (Wash.), 55, 1628-1635.

Klein, G., Clifford. P., Klein, E., Smith, R. T., Minowada, J., Kourilsky, F. M., and Burchenal, J. H. (1967). Membrane immunofluorescence reactions of Burkitt lymphoma cells from biopsy specimens and tissue cultures. J. nat. Cancer Inst., 39, 1027-1044.

Klein, G., Pearson, G., Henle, G., Henle, W., Diehl, V., and Niederman, J. C. (1968). Relation between Epstein-Barr viral and cell membrane immunofluorescence in Burkitt tumo cells. II. Comparison of cells and sera from patients with Burkitt's lymphoma and infectious mononucleosis. J. exp. Med., 128, 1021-1030.

Klemola, E., and Kääriäinen, L. (1965). Cytomegalovirus as a possible cause of a disease resembling infectious mononucleosis. Brit. med. J., 2, 1099-1102. 
Klemola, E., von Essen, R., Henle, G., and Henle, W. (1970). Infectious-mononucleosis-like disease with negative heterophli agglutination test: clinical features in relation to $\mathrm{EB}$ and $\mathrm{CMV}$ antibodies. J. infect. Dis., 121, 608-614.

Lamb, S. G., and Stern, H. (1966). Cytomegalovirus mononucleosis with jaundice as presenting sign. Lancet, 2, 1003-1006.

Lampkin, B. C., Canales, L., and Mauer, A. M. (1967). Infectious mononucleosis in a child with acute lymphoblastic leukemia. J. Pediat., 71, 876-877.

Landon, J. C., and Malan, L. B. (1971). Seroepidemiologic studies of EBV antibody in monkeys. $J$. nat. Cancer Inst., 46, 881-884.

Lehane, D. E. (1970). A seroepidemiolcgic study of infectious mononucleosis: the development of EB virus antibody in a military population. J. Amer. med. Ass., 212, 2240-2242.

Levine, P. H., Ablashi, D. V., Berard, C. W., Carbone, P. P., and Waggoner, D. E. (1970). Elevated antibody titers to HTV in Hodgkin's disease. (Abstr.). Proc. Amer. Ass. Cancer Res., 11, 49.

Lukes, R. J., Tindle, B. H., and Parker, J. W. (1969). Reed-Sternberg like cells in infectious mononucleosis. (Letter to the Editor). Lancet, 2, 1003-1004.

McMahon, N. J., Gordon, H. W., and Rosen, R. B. (1970). ReedSternberg cells in infectious mononucleosis. Amer. J. Dis. Child., 120, 148-150.

Newell, K. W. (1957). The reported incidence of glandular fever: an analysis of a report of the Public Health Laboratory Service. J. clin. Path., 10, 20-22.

Niederman, J. C., Evans, A. S., Subrahmanyan, L., and McCollum, R. W. (1970). Prevalence, incidence and persistence of EB virus antibody in young adults. New Engl. J. Med., 282, 361-365.

Oettgen, H. F., Aoki, T., Geering, G., Boyse, E. A., and Old, L. J. (1967). Definition of an antigenic system associated with Burkitt's lymphoma. Cancer Res., 27, 2532-2534.

Old, L. J., Boyse, E. A., Oettgen, H. F., de Harven, E., Geering, G., Williamson, B., and Clifford, P. (1966). Precipitating antibody in human serum to an antigen present in cultured Burkitt's lymphoma cells. Proc. nat. Acad. Sci. (Wash.), 56, 1699-1704.

Ono, K., Tanabe, S., Naito, M., Doi, T., and Katc, S. (1970). Antigen common to a herpes type virus from chickens with Marek's disease and EB virus from Burkitt's lymphoma cells. Biken's J., 13, 213-217.

Pearson, G. R., Henle, G., and Henle, W. (1971). Production of antigens associated with EBV in experimentally infected lymphoblastoid cell lines. J. nat. Cancer Inst., 46, 1243-1250.

Pereira, M. S., Blake, J. M., and Macrae, A. D. (1969). EB virus antibody at different ages. Brit. med. J., 4, 526-527.

Pope, J. H., Horne, M. K., and Scott, W. (1968). Transformation of foetal human leukocytes in vitro by filtrates of a human leukaemic cell line containing herpes-like virus. Int. J. Cancer, 3, 857-866.

Pope, J. H., Horne, M. K., and Wetters, E. J. (1969). Significance of a complement-fixing antigen associated with herpes-like virus and detected in the Raji cell line. Nature (Lond.), 222, 186-187.

Ragab, A. H., and Vietti, T. J. (1969). Infectious mononucleosis, lymphoblastic leukemia, and the EB virus. Cancer (Philad.), 24, 261-265.

Rapp, F. (1968). The role of the viral genome in oncogenesis. Cancer Res., 28, 1832-1834.

Rapp, F., Butel, J. S., Feldman, L. A., Kitahara, T., and Melnick, J. L. (1965). Differential effects of inhibitors on the steps leading to the formation of SV40 tumor and virus antigens. J. exp. Med., 121, 935-944.

Roizmann, B. (1971). Herpes viruses, membranes and the social behaviour of infected cells. In Viruses Affecting Man and Animals, edited by M. Saunders and W. H. Green. St. Louis, Missouri.
Roizman, B., and Spring, S. B. (1967). Alteration in immunologic specificity of cells infected with cytolytic viruses. In CrossReacting Antigens and Neo-Antigens: $A$ Conference, edited by J. J. Trentin, pp. 85-97. Williams and Wilkins, Baltimore, 1967.

Sawyer, R. N., Evans, A. S., Niedermann, J. C., and McCollum, R. W. (1971). Prospective studies of a group of Yale University freshmen. I. Occurrence of infectious mononucleosis. J. infect. Dis., 123, 263-270.

Shigeta, S., Minowada, J., and Moore, G. E. (1971). Two different complement fixing antigens found in the Burkitt lymphoma cell cultures. Arch. ges. Virusforsch., 33, 182-186.

Sohier, R. (1970). Etude immunologique longitudinale retrospective de l'evolution des anticorps reagissant avec le virus herpetique Epstein-Barr. C.R. Acad. Sci. (Paris), 271, Ser. D. 1231-1232.

Spear, P. G., Keller, J. M., and Roizman, B. (1970). Proteins specified by herpes simplex virus. II. Viral glycoproteins associated with cellular membranes. J. Virol., 5, 123-131.

Stevens, D. A., Levine, P. H., Lee, S. K., Sonley, M. J., and Waggoner, D. E. (1971). Concurrent infectious mononucleosis and acute leukemia. Amer. J. Med., 50, 208-217.

Stevens, D. A., and Pry, T. W. (1971). EB virus antibodies in posttransfusion mononucleosis and cardiopulmonary bypass. $J$. med. Microbiol., 4, 13-18.

Stevens, D. A., Pry, T. W., and Blackham, E. A. (1970). Prevalence of precipitating antibody to antigens derived from Burkitt lymphoma cultures infected with herpes-type virus (EB virus) Blood, 34, 263-275.

Stevens, D. A., Pry, T. W., and Manaker, R. A. (1970). Infectious mononucleosis-always a primary infection with herpes-type virus? J. nat. Cancer. Inst., 44, 535-537.

Sutton, R. N. P., Almond, E. J. P., Marston, S. D., and Emond, R. T. D. (1971). Complement-fixing and fluorescent antibodies in diagnosis of EB virus infections. (Letter to the Editor). Lancet, 2, 1095.

Sutton, R. N. P., Marston, S. D., and Emond, R. T. D. (1971). Some observations on complement-fixing antibodies to the EB virus. J. clin. Path., 24, 801-804.

University Health Physicians and P.H.L.S. Laboratories Joint Investigation (1971). Infectious mononucleosis and its relationship to EB virus antibody. Brit. med. J., 5, 643-646.

Vonka, V., Benyesh-Melnick, M., Lewis, R. T, and Wimberly, I. (1970). Some properties of the soluble (S) antigen of cultured lymphoblastoid cell lines. Arch. ges. Virusforsch., 31, 113-124.

Vonka, V., Benyesh-Melnick, M., and McCombs, R. M. (1970) Antibodies in human sera to soluble and viral antigens found in Burkitt lymphoma and other lymphoblastoid cell lines. $J$. nat. Cancer Inst., 44, 865-872.

Wahren, B., Lantorp, K., Sterner, G., and Espmark A. (1970). EBV antibodies in family contacts of patients with infectious mononucleosis. Proc. Soc. exp. Biol. (N.Y.), 133, 934-939.

Waldenström, J. G. (1968). Monoclonal and Polyclonal Hypergammaglobulinemia. Cambridge University Press, London.

Walters, M. K., and Pope, J. H. (1971). Studies of EB virus related antigens of human leukocyte cell lines. Int. J. Cancer, 8, 32-40.

Wollheim, F. A., and Williams, R. C., Jr. (1966). Studies on the macroglobulins of human serum. 1. Polyclonal immunoglobulin class $M$ (IgM). Increase in infectious mononucleosis. New Engl. J. Med., 274, 61-67.

Zur Hausen, H., Henle, W., Hummeler, K., Diehl, V., and Henle, G. (1967). Comparative study of cultured Burkitt tumor cells by immunofluorescence, autoradiography and electron microscopy. J. Virol., 1, 830-837.

Zur Hausen, H., and Schulte-Holthausen, H. (1970). Presence of EB virus nucleic acid homology in a 'virus-free' line of Burkitt tumour cells. Nature (Lond.), 227, 245-248. 